\title{
Thelazia callipaeda discovered by chance during cataract surgery
}

\author{
Jung-Hun Kim, Seung-Jun Lee, Moosang Kim
}

Kangwon National University, Chuncheon-Si, Korea

\section{Correspondence to} Professor Moosang Kim, kimmoo-79@hanmail.net

\section{DESCRIPTION}

A 79-year-old man presented to our institution with discomfort and dimness of vision in the left eye. On examination, his visual acuity was $20 / 40$ in the right eye and 20/100 in the left eye. The intraocular pressures were $16 \mathrm{~mm} \mathrm{Hg}$ in both eyes. Slit-lamp examination revealed conjunctival hyperaemia and nuclear sclerotic cataracts bilaterally. The patient requested left eye cataract surgery to be performed. Seven days after presentation, we performed cataract surgery on his left eye. After topical anaesthesia, the ocular surface was irrigated with $5 \%$ povidone-iodine solution for $30 \mathrm{~s}$. At that time, we observed a white, thread-like, live and mobile worm in the lower conjunctival sac (figure 1). However, a few seconds later the worm was dead. We recommended that the cataract surgery be delayed. The patient agreed and the cataract surgery was delayed for a month. The worm was

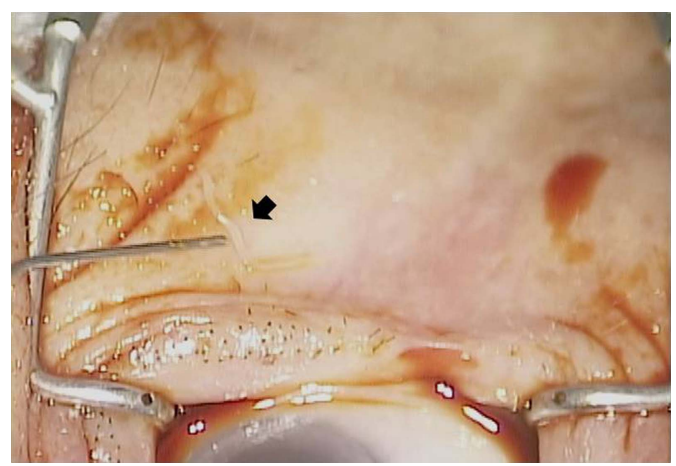

Figure 1 Photograph of the collected Thelazia callipaeda (arrow) from patient's eye (gross appearance). removed with a pair of forceps, and was identified as an adult male Thelazia callipaeda (figure 2A,B). In addition, pharmacological treatment was not needed.

T callipaeda is a parasitic nematode and the most common cause of thelaziasis in humans and dogs. Its presence in the conjunctival sac causes lacrimation and irritation. Case reports of human thelaziasis has increased in several areas of Asia, predominantly in rural communities with poor living and socioeconomic standards and mainly affects the elderly. ${ }^{1}$ In this instance, the patient engaged in farming activity which involved the gathering of wild vegetables in the mountains. Dogs were also raised in his residential village.

\section{Learning points}

Although Thelazia callipaeda infestation is rare, it may be a cause for ocular discomfort.

- T callipaeda usually lies in the conjunctival sac or lacrimal apparatus, causing ocular surface disease.

- Always keep in mind that a detailed history and careful slit-lamp examination are the most important tools required for a correct diagnosis.

Contributors JHK, SJL and MK treated the patient and in doing so acquired the case data. They were also involved in the drafting of the manuscript. All the authors read and approved the final manuscript.
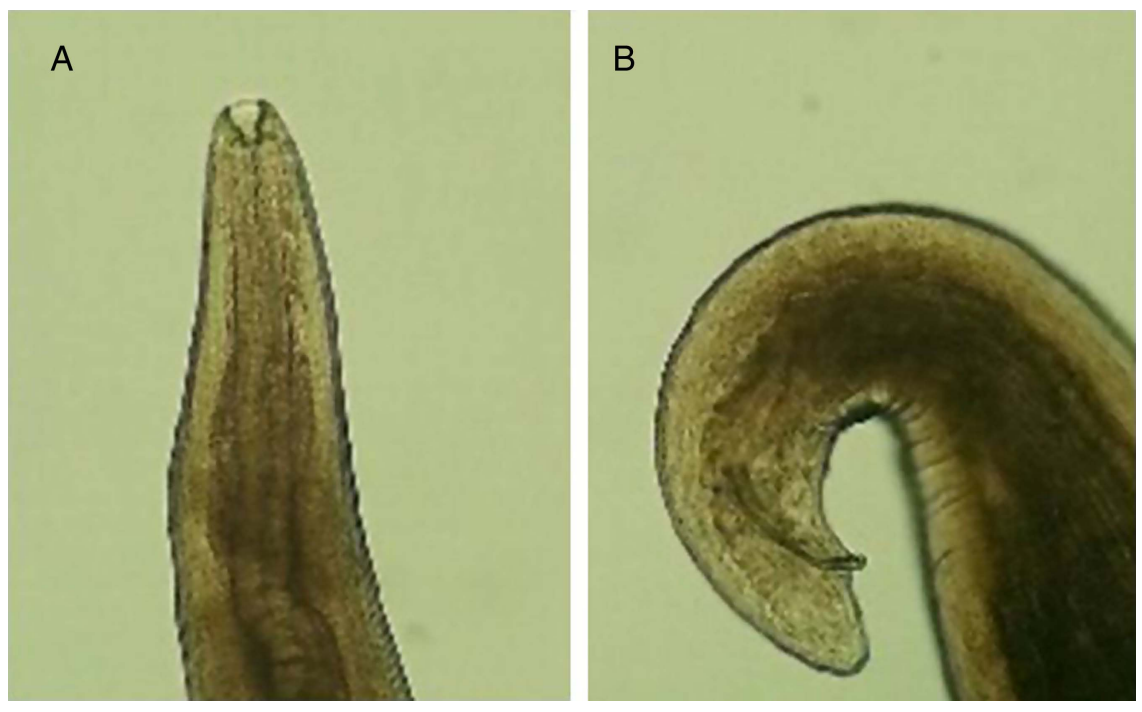

Figure 2 Light microscopic views of the Thelazia callipaeda male worm; head part (A) and tail part (B). 
Funding This study was supported by the 2012 Research Grant from Kangwon National University.

Competing interests None.

Patient consent Obtained.

Provenance and peer review Not commissioned; externally peer reviewed.

\section{REFERENCE}

1 Shen J, Gasser RB, Chu D, et al. Human thelaziosis: a neglected parasitic disease of the eye. J Parasitol 2006;92:872-5.

Copyright 2013 BMJ Publishing Group. All rights reserved. For permission to reuse any of this content visit http://group.bmj.com/group/rights-licensing/permissions.

BMJ Case Report Fellows may re-use this article for personal use and teaching without any further permission.

Become a Fellow of BMJ Case Reports today and you can:

- Submit as many cases as you like

- Enjoy fast sympathetic peer review and rapid publication of accepted articles

- Access all the published articles

- Re-use any of the published material for personal use and teaching without further permission

For information on Institutional Fellowships contact consortiasales@bmjgroup.com

Visit casereports.bmj.com for more articles like this and to become a Fellow 